\title{
Meningkatkan Kemandirian Santri Melalui Pendampingan Konseling Sebaya (Peer Counseling)
}

Received June 18, 2020 | Accepted June 24, 2020

\author{
Elok Halimatus Sadiyah \\ elok@psi.uin-malang.ac.id
}

Fina Hidayati

f.guidance@yahoo.com

Universitas Islam Maulana Malik Ibrahim Malang

\begin{abstract}
Islamic boarding schools are the best alternative in the world of education to print students to grow and develop into religious, disciplined, and independent individuals. However, the reality in the field of chlm.lenges is very heavy, so it is necessary to support programs in the effectiveness of increasing independence of students, one of which is through peer counseling (peer counseling). This community service aims to increase the independence of students through peer counseling assistance at the Darunnajah Karangploso Islamic Boarding School in Malang, involving as many as 406 students. The method used is action research, with the main research question being how peer counseling can improve students' independence. The results of the study prove that the peer counseling model in the Darunnajah Islamic Boarding School in Malang increases the independence of students through: first, students' problem solving skills with peers. Second, students' ability to learn to control behavior. Third, peers are able to provide social, moral and emotional support. Fourth, peer groups are able to provide social support and motivation.
\end{abstract}

Keyword: Peer Counseling, Santri, Independence

\begin{abstract}
Abstrak. Pesantren merupakan alternative terbaik dalam dunia pendidikan untuk mencetak santri tumbuh dan berkembang menjadi pribadi yang religious, disiplin dan mandiri. Namun, kenyataan di lapangan tantangannya sangat berat, sehingga diperlukan program pendukung dalam efektifitas peningkatan kemandirian pada santri, salah satunya yakni melalui konseling sebaya (peer counseling). Tujuan penelitian ini memaparkan peningkatkan kemandirian santri melalui pendampingan konseling sebaya di Pesantren Darunnajah Karangploso Malang, melibatkan santri sebanyak 406 santri. Metode yang digunakan adalah action research, dengan pertanyaan penelitian utama adalah bagaimana pendampingan konseling sebaya dapat meningkatkan kemandirian santri. Hasil penelitian membuktikan bahwa model konseling sebaya (peer counseling) di Pesantren Darunnajah Malang meningkatkan kemandirian santri melalui: pertama, ketrampilan pemecahan masalah Santri dengan teman sebaya. Kedua, kemampuan santri belajar mengontrol perilaku. Ketiga,teman sebaya mampu memberikan dukungan sosial, moral dan emosional. Keempat, Kelompok teman sebaya mampu memberikan dukungan sosial dan motivasi.
\end{abstract}

Kata Kunci: Konseling sebaya, Santri, Kemandirian

\section{PENDAHULUAN}

Sikap mandiri sangatlah penting bagi setiap remaja yang menjadi peserta didik, tidak terkecuali remaja santri. Kemandirian akan mengarahkan remaja kearah yang lebih positif, mampu melatih kebiasaan yang baik dan juga mengatur setiap tindakannya (Niswara \& Setyawati, 2016). Berbagai fenomena yang menunjukkan kurangnya kemandirian remaja seringkali pada akhirnya akan mengarahkan perilaku yang tidak 
bertanggung jawab, seperti perkelahian antar pelajar, tingginya angka pengangguran disetiap jenjang pendidikan, bahkan berbagai perilaku kriminal. Mereka yang kurang mandiri akan memiliki ketergantungan tinggi kepada orang lain, malas, lemah semangat dan enggan berusaha, sehingga menghambat perkembangan potensi-potensi psikologis yang diperlukan dalam hidup. Hurlock (2011) mengemukakan bahwa sebenarnya remaja sangat mendambakan kemandirian dan berusaha untuk mengurangi ketergantungannya pada orang lain, baik dilingkungan sekolah maupun di luar sekolah. Namun demikian tidak selamanya usaha memperoleh kemandirian tersebut berjalan mulus karena membutuhkan dukungan dari pihak luar, terutama di lingkungan tempat remaja tinggal, salah satunya adalah di pesantren.

Pesantren merupakan alternatif terbaik dalam dunia pendidikan untuk mencetak seorang santri tumbuh dan berkembang menjadi pribadi yang religious, disiplin, dan mandiri. Namun, proses tersebut tidak mudah karena membutuhkan waktu yang cukup panjang dan proses yang cukup komplek. Kenyataannya beberapa santri tidak mudah dalam menyesuaikan diri, kurang mampu mengambil keputusan secara mandiri, masih bingung menetapkan tujuan hidup, juga kurang cakap dalam menyelesaikan problem yang dihadapi (Niswara \& Setyawati, 2016). Padahlm. dengan pembagian tugas non formal di pesantren dan tugas akademik di sekolah, santri memiliki tanggung jawab lebih besar dibanding remaja yang tinggal dirumah (Munawarah, 2016), sehingga kemandirian yang dituntut juga lebih besar. Ironisnya dalam sebuah penelitian ditemukan remaja yang tinggal di Pesantren lebih rendah kemandiriannya dibanding remaja yang tinggal di rumah (Kamiliyah \& Ervina, 2015).

Studi pendahuluan dan observasi di Pesantren Darunnajah Karangploso Malang, yang memiliki santri lebih dari 500 orang, menemukan problem ketidakmandirian sebagai berikut, (1) Beberapa santri, terutama santri baru memiliki masalah penyesuaian diri; (2) Beberapa santri belum mampu mandiri dalam hlm. kebersihan diri dan lingkungan, (3) Beberapa santri belum mampu mandiri dalam pengambilan keputusan dan problem solving. Berdasarkan fenomena tersebut maka peneliti tertarik untuk berupaya meningkatkan kemandirian santri dengan melakukan pendampingan konseling sebaya. Pendampingan konseling sebaya dipilih sesuai dengan karakteristik fase remaja dimana teman sebaya merupakan significant others yang sangat berpengaruh dalam hidup remaja (Hurlock, 2011). Efektifitas konseling sebaya terhadap peningkatan potensipotensi psikologis dan perilaku positif remaja telah banyak dibuktikan dalam berbagai penelitian. Diantaranya adalah penelitian yang menemukan efektifitas konseling sebaya pada peningatan perilaku prososial remaja (Kadarsih, 2017), konseling sebaya efektif berpengaruh pada peningkatan empati remaja (Suryawati, dkk.,2016), konseling sebaya efektif dalam peningkatan kemandirian belajar siswa (Febrianti, 2018).

Konseling sebaya merupakan tingkah laku membantu secara interpersonal kepada individu lain yang dilakukan oleh individu nonprofesional yang sama usianya.Dalam konseling sebaya program konseling dilaksankan oleh santri terhadap santri lainnya yang membutuhkan bantuan dalam menyelesaikan problem akademik maupun non akademik mereka. Menurut Kan (1996), terdapat elemen pokok dari konseling teman sebaya yang perlu untuk dipenuhi, yakni: (1) Premis dasar yang mendasari konseling teman sebaya adalah bahwa pada umumnya individu mampu menemukan solusi dari berbagai kesulitas yang dialami dan mampu menemukan cara mencapai tujuan masingmasing; (2) Kenyataan bahwa konselor sebaya yakni seorang teman sebaya dari konseli yang menyediakan kontak diantara keduanya, mereka memiliki pengalaman hidup yang 
sama yang memungkinkan membuat konseli rileks, memungkinkan bertukar pengalaman, dan menjaga rahasia tentang yang dibicarakan dan dikerjakan dalam

pertemuan tersebut; (3) Terdapat kesamaan kedudukan(equality) antara konselor teman sebaya dengan konseli, meskipun peran masing-masing berbeda; (4) Tehnik yang digunakan adalah membuat konseli memperoleh pemahaman dan pengalaman tentang dirinya dan mengembangkan potensi pribadinya; (5) Keputusan kapan akan dimulai dan diakhiri konseling teman sebaya, terletak pada konseli; (6) Teman sebaya dapat berupa seseorang yang memiliki situasi yang sama atau usia yang sebaya, atau seseorang yang memilki latar belakang dan budaya yang sama sedangkan langkah-langkah yang dilaksanakan dalam pembentukan konseling sebaya meliputi beberapa tahapan (Sujarwo, 2005), yakni memilih calon konselor sebaya, memberikan pelatihan, dan mengorganisir pelaksanaan konseling sebaya. Melalui konseling sebaya diharapkan terjadi peningkatan kualitas kemandirian santri dalam beberapa aspek Kemandirian merupakan kemampuan untuk mengarahkan dan mengendalikan diri sendiri dalam berpikir dan bertindak, serta tidak merasa bergantung pada orang lain secara emosional (Stein \& Book, 2000). Dalam hlm. ini santri yang mandiri tidak akan bergantung pada bantuan orang lain dalam memenuhi kebutuhan dirinya secara fisik, juga dalam hlm. pengambilan keputusan, serta dalam berinteraksi social. Menurut Stenberg (1993) kemandirian terdiri dari tiga jenis, yaitu (1) kemandirian emosional, yakni aspek kemandirian yang merujuk pada perubahan kedekatan hubungan emosional antar individu, seperti berubahnya hubungan emosional anak saat remaja dengan orangtuanya; (2) kemandirian tingkah laku merujuk kepada kemampuan seseorang dalam berperilaku secara bebas tanpa harus melanggar aturan yang berlaku, dan (3) kemandirian nilai yakni kepada kemampuan seseorang dalam mengambil keputusan dan menetapkan pilihan keputusannya dengan tetap berpegang teguh pada dasar prinsip-prinsip nilai individual yang dimilikinya, bukan mengambil prinsip orang lain.

Melalui pengabdian masyarakat berbasis riset, maka tujuan penelitian yakni memaparkan kemandirian santri dan memaparkan efektifitas pendampingan konseling sebaya terhadap peningkatan kemandirian santri.

\section{METODE}

Metode yang digunakan dalam Pengabdian Masyarakat di Pesantren Darun Najah Malang ini yakni pengabdian masyarakat dengan pendekatan action research, berupa pendampingan konseling sebaya (peer counseling). Instrumen dalam penelitian yang digunakan yakni angket kemandirian, observasi, dan wawancara. Kegiatan pengabdian melalui beberapa tahapan yakni; (1) need assesment untuk mengetahui permasalahan yang terjadi pada santri, pengurus pondok yang notabene juga sebagai santri, serta ustadz dan usatdzah yang berada di Pesantren. Selain itu juga dilakukan asessment tentang apa kebutuhan dan harapan santri untuk menyelesaikan problem mereka di pesantren. Hlm. ini dilakukan agar mendapatkan gambaran menyeluruh persoalan kemandirian yang terdapat pada diri santri serta solusi efektif yang diharapkan, (2) pemilihan responden yang akan dilatih menjadi konselor sebaya, (3) pelatihan dasar konseling sebaya (4) pengukuran kemandirian setelah dilakukan pendampingan konseling sebaya.

Pengabdian masyarakat dilaksankan dengan melibatkan 406 santri dengan rumusan keterlibatan sebagai berikut.

1. Kebutuhan need assessment melibatkan 30 santri laki-laki, 30 santri perermpuan, 30 pengurus pondok perempuan, 30 pengurus pondok laki-laki, 25 ustadzah, dan 15 ustadz. 
2. Pelatihan konselor sebaya (peer counseling); 20 santri laki-laki, 20 santri perempuan, 10 pengurus pondok laki-laki, 10 pengurus pondok perempuan, 3 ustadah dan 3 ustadz.

3. Penyebaran angket kemandirian; 90 santri laki-laki dan 90 santri perempuan

\section{HASIL}

Kegiatan pendampingan konseling sebaya telah dilaksanakan dengan baik sesuai rencana yang ditetapkan. Pelaksanaan Kegiatan dilaporkan melalui tahapan-tahapan berikut.

Pertama, hasil dari asesmen sebagai tahapan awal kegiatan pengabdian yang dilakukan, menunjukkan tingkat kemandirian Santri berada pada level sedang cenderung rendah. Hlm. tersebut tercermin dari berbagai permasalahan kemandirian santri yakni,

a. santri belum memiliki role model di pesantren. Hlm. ini mengakibatkan tidak adanya kesadaran santri dalam menaati peraturan yang berlaku di pesantren. Intensitas pelanggaran peraturan yang meningkat setiap tahun, misal; tidak mengikuti pelajaran di kelas, tidur di kelas, tidak mengikuti sholat berjamaah, dan lain sebagainya,

b. banyak permasalahan pribadi santri yang tidak mampu diselesaikan, sehingga berdampak pada permasalahan di pesantren. Tidak adanya pendekatan yang tepat pada penyelesaian masalah santri membuat mereka tidak mampu mengurai masalah yang ada. Hlm. tersebut membuat santri, tidak memiliki semangat belajar, tidak kerasan di pesantren dan akhirnya malas untuk mengikuti pelajaran di sekolah,

c. manajemen waktu yang kurang baik, membuat santri memiliki rencana kegiatan yang kurang baik. Dalam kegiatan di Pesantren, jadwal sangat padat, sehingga ketidakmampuan santri dalam mengatur waktu membuatnya tidak displin. Misalnya, terlambat masuk kelas, tidak mengerjakan tugas sampai selesai dan menggunakan waktu belajarnya dengan banyak tidur di kelas.

Setelah mendapatkan data tentang persoalan santri yang mengarah pada kurangnya kemandirian, maka tahapan berikutnya yang dilakukan adalah melakukan need assesment kedua tentang kebutuhan dan harapan santri terkait strategi menyelesaikan problem yang dihadapi di lapangan, agar lebih tepat sasaran. Data menunjukkan santri merasa hanya menjadi objek punishment, namun tidak solutif, dan terjadi hambatan komunikasi secara efektif hingga membuat hubungan menjadi kurang harmonis dengan ustadz atau ustadzahnya. Berdasarkan hasil tersebut maka pendampingan konseling sebaya menjadi solusi yang ditawarkan dengan asumsi bahwa pendekatan konseling sebaya di usia remaja akan lebih efektif dalam menjawab persoalan santri/

Kedua, pemilihan responden yang akan dilatih menjadi konselor sebaya. Pada tahapan ini terpilih 20 Santri laki-laki, 20 Santri Perempuan, 10 Pengurus Pondok lakilaki, 10 Pengurus pondok perempuan, 3 ustadah dan 3 ustadz sebagai peserta yang akan mendapatkan pelatihan dasar konseling sebaya.

Ketiga, pendampingan dan pelatihan dasar konseling sebaya. Tujuan dari kegiatan ini adalah: Memperkenalkan program konseling sebaya sebagai alternatif pemecahan masalah (problem solving) bagi para santri, Memberikan pengetahuan dan pemahaman tentang proses dasar konseling sebaya, Membentuk karakteristik dasar seorang konselor sebaya, Meningkatkan kepekaan terhadap lingkungan sekitar, Membantu pengelola pesantren dalam mengelola berbagai permasalahan yang ada di tempat tersebut melalui program konseling sebaya.

Keempat, melakukan upaya peningkatan kemandirian santri melalui pendampingan konseling sebaya (peer counseling) dengan pengawalan dari tim pengabdian masyarakat. Pada tahapan ini peserta konselor sebaya mendapatkan pendampingan tim pengabdian 
masyarakat dalam melaksankan konseling sebaya untuk memastikan bahwa kegiatan konseling dilakukan secara tepat dan memiliki kemampuan dasar yang dibutuhkan saat melakukan konseling sebaya.

Kelima, pengukuran kemandiriaan santri setelah dilakukan pendampingan konseling sebaya. Proses pengukuran dilakukan dengan cara menyebar angket kemandirian pada 180 santri dan wawancara pada beberapa perwakilan santri. Dari pengukuran yang dilakukan ditemukan hasil berikut.

a. Dengan kelompok konseling sebaya ini, maka santri mampu mendapatkan contoh model perilaku tentang kemandirian. Pengaruh perilaku teman sebaya bisa diinternalisasi dan menjadi perilaku individu. Misalnya, pada kegiatan sekolah dan belajar di Pesantren. Intensitas pelanggaran peraturan semakin menurun, tingkat kepatuhan pada aturan pesantren semakin meningkat.

b. Permasalahan santri sudah mulai terurai. Dengan pendekatan konseling sebaya, maka pendampingan kemandirian Santri langsung tepat sasaran. Pendekatan sebaya efektif dalam tahap usia remaja, karena pengaruh terbesar diusia remaja adalah peer group. Dengan terbantunya permasalahan santri, santri lebih mampu meningkatkan kemandirian dalam berbagai hlm., diantaranya kemandirian terkait kebersihan diri dan lingkungan, lebih mampu menyelesaikan menganalisis persoalan yang dihadapi dan menyelesaikannya.

Adanya support system berupa kelompok konselor sebaya di Pesantren Darunnajah, dengan pembina yang dipilih dari ustadz dan ustadzah membuat pendampingan kemandirian ini menjadi solusi yang dibutuhkan santri. Peraturan dan sistem di Pesantren yang penuh dengan nilai-nilai religiusitas tinggi dan sistem salafi yang diberlakukan menuntut perilaku kesopanan dan unggah-ungguh harus ditonjolkan. Dengan pendekatan konseling sebaya terjadi perubahan perilaku santri menjadi lebih sesuai dengan budaya pesantren

\section{DISKUSI}

Penelitian yang mendukung hasil pengabdian masyarakat berbasis riset ini cukup banyak, antara lain penelitian dari Endang (2006) yang membuktikan bahwa konseling teman sebaya (peer counseling) sangat penting bagi remaja dalam menghadapi permasalahan di era globalisasi yang semakin kompleks. Kompleksitas persoalan tersebut menuntut remaja untuk semakin mandiri dalam melakukan pengambilan keputusan dengan segala persoalan yang dihadapi. Penelitian Atika, Hastiani dan Rustam (2016), tentang bimbingan kelompok melalui pendekatan tutor sebaya untuk meningkatkan kemandirian belajar siswa di SMP N 2 Pontianak. Dalam penelitian tersebut konseling sebaya terbukti efektif dalam meningkatkan kemandirian belajar siswa.Tidak hanya kemandirian belajar, namun keputusan pemilihan jurusan juga lebih efektif dengan menggunakan pendekatan konseling sebaya. Penelitian Fajaria, Marjohan \& Sukmawati (2013) yang dilakukan di SMA X kelas XI, dengan sampel sebanyak 64 orang menunjukkan melalui konseling sebaya tingkat kemandirian siswa semakin tinggi yakni pada aspek kepercayaan diri dan optimisme dalam menentukan pilihan jurusan .

Remaja dengan segala tantangannya akan banyak mengalami permasalahan, baik persoalan berkaitan dengan pemenuhan tugas perkembangan maupun berkaitan dengan stimulasi dari luar. Apalagi dengan label masa storm and drung yang melekat pada remaja membuat masa remaja identik dengan berbagai persoalan. Hlm. ini menjadikan remaja sangat membutuhkan kemandirian, baik kemandirian emosi, kemandirian pengambilan 
keputusan dan perilaku maupun kemandirian nilai (Santrock, 2011). Kemandirian akan membuat remaja berkembang menjadi manusia dewasa dengan kualitas hidup yang baik. Dalam pengadian berbais riset ini kemandirian remaja dalam hal ini santri remaja dapat ditingkatkan dengan menggunakan pendekatan konseling sebaya. Hasil ini mendukung penelitian sebelumnya yang membuktikan tentang efektifitas konseling sebaya dalam peningkatan potensi psikososial remaja. Hlm. ini dapat dimaklumi karena karakteristik khas remaja yang didominasi oleh pengaruh eksternal terutama yakni teman sebayanya (Mastroleo, Turissi, Carney, Ray \& Larimer, 2011).

Dampak positif yang ditemukan dari hasil pendampingan konseling sebaya menunjukkan bahwa keberadaan teman sebaya memiliki berbagai peranan substantif bagi remaja dalam mengatasi permasalahan kemandirian sebagai berikut.

a. Mengajarkan keterampilan memecahkan masalah.

Santri merasa bahwa dengan bercerita kepada teman sebaya dapat membuat mereka lebih nyaman, lebih memahami perasaan diri sendiri, dan lebih memiliki kemampuan untuk menganalisis suatu masalah dengan cara mendiskusikannya, serta lebih mampu memecahkan masalah yang mereka dihadapi. Hlm. ini sesuai dengan apa yang dikemukakan oleh Schneider (dalam (Kurniawan \& Sudrajat, 2018) bahwa teman sebaya mengajarkan beberapa hlm. kepada anak, salah satunya adalah mengajarkan keterampilan dalam memecahkan masalah, terutama terhadap sesama anggota kelompok.

b. Belajar berinteraksi dan mengontrol perilaku

Santri menyatakan bahwa dengan pendampingan konseling sebaya mereka lebih mampu mengontrol diri dan perilaku sesuai dengan standar norma yang ada di lingkungan pesantren. Hlm. ini karena dalam konseling sebaya terjadi proses pengungkapan diri yang lebih bebas dan lebih terbuka antara satu santri dengan santri lainnya sehingga mengurai persoalan, dan mengurangi perasaan lonelinnes yang mereka rasakan.

c. Memberikan dukungan sosial, moral, dan emosional

Sebagian besar santri mengatakan bahwa mereka lebih nyaman untuk bercerita tentang masalah yang dihadapinya dengan teman sebaya dari pada bercerita kepada guru maupun ustadz dan ustadzah. Hlm. ini didasari oleh beberapa hlm. seperti persamaan usia, pengalaman serta masalah yang mereka. Similarity ini akan memberikan efek saling menguatkan satu sama lain, menjadi sumber spendukung sosial yang efektif tanpa ada prasangka usia.

d. Memberikan dorongan dan motivasi

Motivasi yang diberikan oleh teman sebaya membuat santri menjadi lebih optimis, serta terpacu dan bersemangat untuk melakukan sesuatu. Santri mengungkapkan bahwa motivasi dari konselor sebaya dapat lebih meningkatkan rasa percaya diri mereka dalam mengatasi masalah dan meminimalisir rasa putus asa.

Berdasarkan penjelasan di atas maka dapat disimpulkan bahwa pendampingan konseling sebaya efektif dalam meningkatkan kemandirian santri melalui peningkatan potensi pengambilan keputusan, problem solving dan juga aspek psikososial lainnya.

\section{KESIMPULAN} berikut.

Kesimpulan dari hasil pengabdian masyarakat yang sudah dilakukan adalah sebagai 
Pertama, kemandirian Santri sebelum diberikan pendampingan antara lain: a) santri belum memiliki role model yang tepat, b) kemampuan dalam penyelesaian masalah pribadi santri rendah, sehingga memiliki efek domino pada munculnya permasalahan yang lain, dan c) ketidakmampuan dalam manajemen waktu dan managemen diri yang baik

Kedua, pendampingan konseling sebaya terbukti efektif dalam meningkatkan kemandirian santri. Hlm. ini dapat dijelaskan sebagai berikut a) adanya role model dari teman sebaya yang mampu memberikan pengaruh pada perilaku mandiri secara positif, santri lebih mampu mengontrol perilakunya terutama terkait kepatuhan pada aturanaturan yang berlaku dipesantren, b) santri mendapatkan pendampingan dari teman sebaya dalam menyelesaikan masalah pribadinya, sehingga membuatnya lebih memiliki kemandirian dalam menganalisis dan menyelesaikan masalah, dan c) adanya support system yaitu konselor sebaya yang akan terus mendampingi santri dengan pembinaan dari ustadz dan ustadzah. Support system dari konselor sebaya tersebut akan memberikan dukungan sosial, moral, emosional juga motivasi pada santri.

\section{SARAN}

Berdasarkan hasil pengabdian masyarakat berbasis riset, terdapat saran-saran sebagai berikut. Pertama, pendampingan Santri melalui konseling sebaya, hendaknya diperluas pada lembaga formal. Sehingga tidak hanya di Pesantren, tapi juga struktur juga diperkuat di Madrasah masing-masing, baik di Madrasah Tsanawiyah maupun Madrasah Aliyah, supaya lebih efektif dan optimal. Kedua, bagi konselor sebaya, dalam jangka waktu tertentu mendapatkan upgradding skill mengenai materi konseling pada Rermaja dan adanya generasi yang berkelanjutan. Ketiga, bagi penelitian selanjutnya mampu mengaitkan efektivitas peer counseling dengan variabel psikologi yang lain, sehingga mengembangkan kajian Ilmu Psikologi di wilayah Pesantren khususnya.

\section{DAFTAR PUSTAKA}

Atika, Amelia, Hastiani \& Rustam. (2016). Bimbingan kelompok melalui pendekatan tutor sebaya untuk meningkatkan kemandirian belajar siswa SMP Negeri 2 Pontianak. Jurnal edukasi. Vol. 14 (1), hlm. 1-11

Ending, Busri. (2006). Konseling teman sebaya pada remaja di era globalisasi. Konseling teman sebaya. hlm.199-210

Fajaria, Deprina., Marjohan., \& Sukmawati, Indah (2016). Kemandirian perilaku peserta didik dalam pemilihan jurusan dan implikasi terhadap pelayanan bimbingan dan konseling. Jurnal ilmiah konseling. Vol. 2 (2), hlm. 1-5

Febrianti, T Dan Rahmah, M. (2018). Efektivitas Pelaksanaan Konseling Teman Sebaya untuk Meningkatkan Kemandirian Belajar Siswa Kelas VII di SMP Tulus Bhakti Bekasi. Guidance 15 (01), 33-42

Hasti, Ridia \& Nurfarhanah. (2013). Hubungan antara interaksi social teman sebaya dengan kemandirian perilaku remaja. Jurnal ilmiah konseling. Vol. 2 (1), hlm. 317323

Hurlock, Elizabeth B. (2011). Psikologi Perkembangan : Suatu Pendekatan Sepanjang Rentang Kehidupan. Jakarta : Erlangga

Kadarsih, S. (1996). Bimbingan Konseling Sebaya dalam Pengembangan Perilaku Prososial Remaja. Tesis tidak diterbitkan. Yogyakarta:UIN Sunan Kalijaga. 
Kan, P. V. (1996). Peer counseling in explanation. (online).

Kamiliyah, Hikmatul \& Ervina, Iin. (2015). Perbedaan kemandirian remaja yang tinggal di pesantren dengan remaja yang tinggal dirumah. Jurnal insight. Vol. 11 (1), hlm. $1-13$

Mastroleo, Nadine R., Turissi, Robb., Carney, J. V., Ray, A. E., \& Larimer, M. E. (2011). Wxamination of post-training supervision of peer counselors in a motivational enhancement intervention to reduce drinking in a sample of heavy drinking college students. HHS Public Access. Vol. 39 (3), hlm. 289-297

Munawarah, Siti. (2016). Upaya Murabby dalam mengembangkan kemandirian santri di Pesantren Mambaul Hisan Kadipaten Ponorogo. Skripsi tidak diterbitkan. STAIN Ponorogo.

Niswara, E.E; Setiawati, D. (2016). Penerapan Media Flash Tentang Tata Tertib Untuk Meningkatkan Pemahaman Kemandirian Santri Pondok Pesantren Al Amanah Junwangi Krian Jurnal BK Unesa.Vol 6, No 2

Santrock. J.W. (2011). Life Span Development. Perkembangan Masa hidup Edisi 11 Jilid 2. Jakarta: Erlangga

Steinberg, L. (1993). Adolescence. International edition third edition. New York: McGraw-Hill.Inc

Steven J. Stein and Howard E. Book, (2000) Ledakan EQ, Terjemahan Trinanda Rainy Januarsari dan Yudhi Murtanto.Kaifa Bandung.

Suryawati, D.P. (2016). Implementasi Pembelajaran Akidah Akhlak Terhadap Pembentukan Karakter Siswa di MTs Negeri Semanu Gunungkidul. Jurnal Pendidikan Madrasah, Volume 1, Nomor 2, h 309-322

Sujarwo (2005). Konseling Teman Sebaya (Peer Counseling) di SMP: Sebuah Peluang yang perlu dimanfaatkan. Makalah Workshop Guru Pembimbing SMP tidak diterbitkan.

Syahputra, Wahyu. (2016). Peran konselor dalam membentuk sikap kemandirian santri panti asuhan nurul Haq Bangun Tapan, Bantul, Yogyakarta. Skripsi tidak diterbitkan. UIN Sunan Kalijaga. 